This is an open access article under the CC BY-NC-ND license (https://creativecommons.org/licenses/by-nc-nd/3.0/) Issue III, November 2020

ISSN 2707-9481

ISBN 978-601-323-207-2

https://doi.org/10.31643/2020.017

\author{
Maiya Myrzabekova \\ Ankara Hac1 Bayram Veli University,Turkey \\ E-mail: maiya.myrzabekova@hbv.edu.tr \\ ORCID ID 0000-0003-2396-1042
}

\author{
Nurlan Akhmetova \\ Kyrgyz National University named after Jusup \\ Balasagyn, Kyrgyzstan \\ E-mail: maiya.myrzabekova@ hbv.edu.tr \\ ORCID ID 0000-0002-8865-9496
}

\title{
Role-play games based on video materials as a means of formation of communicative competence in learning Russian as a foreign language
}

\begin{abstract}
Transition to distance learning in a pandemic and changes of the technological sphere not only entail changes in the system of values of the society, but also have a direct impact on the processes in the educational sphere. The teacher is in a constant mode of "innovative search", associated with changing approaches to the formation of the educational process. The creation of real and imagined situations of communication at a lesson of Russian language with the use of various techniques and methods of works (role-play, discussions, projects, etc.) with the use of video currently is an integral part of the educational process and a real help in the work of the teacher. The purpose of this study is to compile and present experience on the use of role-play games "Tour" and the show "Everything about Russia" in the integration (in the educational field). The games are built on the main topic and the gradual division of the proposed video to enhance the quality of learning and interest in learning the subject, studying natural communication that allows students be more active in the process of development of the Russian language and encourage them to improve their communicative skills, to widen, deepen professional knowledge and enrich their language and cross-cultural stock of knowledge. We found that the use of interactive role-play methods and various ICT (information and communication technologies) tools not only increases the interest in language learning, but also creates an illusion of participation in the real life of the country, the language of which is being studied. This in its turn increases the motivation of students, provides a direct perception and study of Russian culture, connects the lesson with the real world that encourages almost genuine communication.
\end{abstract}

Keywords: Russian language, innovative technologies, video materials, communicative competence, interactive methods, teaching methods, pedagogy, role-play game.

Cite this article as: Myrzabekova M., Akhmetova N., (2020). Ispol'zovaniye rolevykh igr na osnove videomaterialov, kak sredstvo formirovaniya kommunikativnykh kompetentsiy v izuchenii russkogo yazyka kak inostrannogo [Role-play games based on video materials as a means of formation of communicative competence in learning Russian as a foreign language]. Challenges of Science. Issue III, p.: 118-130. https://doi.org/10.31643/2020.017

Майя Мырзабекова

Анкарский Университет Хаджы Байрама Вели, Турция

E-mail: maiya.myrzabekova@hbv.edu.tr ORCID ID 0000-0003-2396-1042
Нурлан Ахметова

Кыргызский Национальный Университет им.Ж.Баласагына, Кыргызстан

E-mail: maiya.myrzabekova@hbv.edu.tr ORCID ID 0000-0002-8865-9496

\section{Использование ролевых игр на основе видеоматериалов, как средство формирования коммуникативных компетенций в}

\section{изучении русского языка как иностранного}

\footnotetext{
Абстракт. Переход на дистанционное обучение в условиях пандемии и изменения технологической сферы не только влекут за собой изменение ценностных ориентаций общества, но и оказали непосредственное влияние
} 
на процессы в образовательной сфере. Преподаватель находится в постоянном режиме «инновационного поиска», связанного с изменением подходов к построению образовательного процесса. Создание реальных и воображаемых ситуаций общения на уроке русского языка с применением различных методов и приемов работ (ролевые игры, дискуссии, проекты и др.) посредством использования видео на уроке русского языка в настоящее время является неотьемлемой частью образовательного процесса и настоящим подспорьем в работе преподавателя. Цель данной работы - обобщить и представить опыт работы по применению ролевых игр «Экскурсия» и телепередача «Все о России» в интеграции (в данном образовательном «поле»), построенных на основной теме и поэтапного деления предлагаемого видеоматериала, способствующих повышению качества обучения и интереса к изучению предмета, обучающих естественной коммуникации, позволяющих активизировать студентов в процессе освоения русского языка и побуждающих к совершенствованию своих коммуникативных умений, расширению, углублению профессиональных знаний и обогащению их языкового запаса и страноведческих знаний. Мы выяснили, что применение интерактивного метода ролевой игры и различных средств ИКТ (информационно-коммуникационные технологии) способствуют не только повышению интереса к изучению языка, но и создают иллюзию участия в реальной жизни страны изучаемого языка, а это в свою очередь повышает мотивацию студентов, обеспечивает непосредственное восприятие и изучение культуры России, связывает занятие с реальным миром, стимулирующее почти подлинную коммуникацию.

Ключевые слова: русский язык, инновационные технологии, видеоматериалы, коммуникативная компетенция, интерактивные методы, методика преподавания, ролевая игра.

Введение. Инновации в развитии экономики и угроза распространения коронавирусной инфекции влекут за собой изменение ценностных ориентаций общества, а значит изменения роли и места образования в жизни этого общества. Инновации в учебном процессе необходимы и можно сказать неизбежны в индустриальную эпоху. Инновации должны найти отражение в формах и методах обучения, научной организации и оснащённости современными научно-техническими средствами учебного процесса, а также в идеях, направлениях. Модернизация содержания образования на современном этапе развития общества связана с инновационными процессами в организации обучения русского языка, соответственно и преподаватель находится в режиме «инновационного поиска», связанного с изменением подходов к построению образовательного процесса. Как показывает практика, большинство педагогов в своей педагогической деятельности, вне зависимости от их стажа и уровня квалификации, испытывает затруднения в осуществлении инновационной деятельности (Мельник,2008).

На сегодняшний день, в дистанционном формате в условиях пандемии преподаватель вынужден организовывать учебный процесс посредством дистанционных технологий и должен уметь не транслировать знания, как это было раньше, а перед ним возникает необходимость поиска новых педагогических инновационных учебных технологий в организации учебно-воспитательного процесса, которые позволят обеспечить высокий уровень знаний студентов, умение самостоятельно приобретать и применять их на практике; развивать каждого как творческую личность, способную к практической работе с различными материалами и инструментами. Среди инновационных технологий можно привести следующие: проектная деятельность, личностно-ориентированное обучение, здоровье сберегающие технологии, исследовательская деятельность, информационно- коммуникативное обучение, игровая методика. Необходимость существенно повысить качество формируемой коммуникативной компетенции студентов требует применения интерактивных методов для совершенствования процесса обучения. Использование интерактивных методов на занятиях русского языка повышает мотивацию обучения, способствует стимулированию положительного отношения студентов к учению.

\section{Методология исследования}

Несмотря на определенный прогресс (использование Интернет, различных программ и т. д.), одной из трудностей обучения иностранному языку является весьма ограниченная, если не сказать скудная, возможность общения с носителями языка и использования навыков разговорной речи вне университета. Современные технологии позволяют нам расширить рамки урока и приводят к необходимости использования новых форм обучения. Продумывая методическую тему, следует использовать нестандартные формы работы, включать в процесс обучения перспективные методические приемы для развития креативных способностей студентов: научно-теоретические семинары, круглые столы, уроки-лекции, уроки-защиты своих научных работ, кластеры, инсерт (при 
самостоятельном изучении теоретического материала), совместный поиск, перекрестную дискуссию, круглый стол; применять элементы технологий решения изобретательских задач: классическое обучение, обучение с помощью аудиовизуальных технических средств, ролевые и деловые игры и др. Несмотря на активное использование видеоматериалов в процессе изучения русского языка, методика работы с видеоматериалами еще недостаточно разработана.

Теоретическая значимость исследования состоит в определении сущности использования поэтапного деления предлагаемого видеоматериала на уроке, которая может быть использована для повышения естественной коммуникации в процессе изучения русского языка во время и вне урочной деятельности студентов.

Практическая значимость: данный опыт работы использования видеоматериалов на уроках русского языка может быть использован в работе преподавателей, студентов - практикантов и также в дистанционном формате.

Целью данной работы - представить опыт работы поэтапного деления предлагаемого видеоматериала и по применению ролевой игры после просмотра видео в образовательном процессе. Специфика видеоматериалов с использованием ролевых игр в дистанционном формате, как средства обучения русскому языку обеспечивает общение с реальными предметами, стимулирующими почти подлинную коммуникацию: студенты как бы «вживаются в роль» и становятся участниками всех обыгрываемых с их помощью ситуаций, играют определенные роли, решают "настоящие", жизненные проблемы. Для создания реальных и воображаемых ситуаций общения в образовательном процессе применяем различные интерактивные методы (ролевые игры, дискуссии, творческие проекты и др.) и различные средства ИКТ (информационно-коммуникационные технологии): аппаратные (компьютер, фотоаппарат, видеокамера, доска, мультимедийный проектор), программные (электронные учебники и словарь, программу «Learnrussian.rt.com», приложения «Talk2Russian», информационные сайты, поисковые системы Интернета). На уроках используем видео ролики «Russian» (Илкера Демира 2), «Чашки» (Златоуст 2010), «Послушайте» выпуск 1-2 включает DVD с видеозаписью (И.А.Гончар, 3 Златоуст, 2013), «Семь прогулок по Москве» (Ю.Е.Прохоров, А.В.Голубева, 2011), «Лингвострановедческая олимпиада» (К.А.Деменева, Л.Е.Адясова 20172 часть ) Златоуст для студентов A1-В1, которые соответствуют изучаемым темам РКИ (видеоэкскурсии по различным городам России и Турции, видеозаписи телевизионных новостей и других телепередач, реклама на русском языке). К данным учебно-методическим комплектам предусмотрено большое количество разнообразных контрольных тестов, творческих самостоятельных и коллективных заданий.

Как отмечает О.И. Барменкова, «несмотря на определенный прогресс (использование Internet, различных программ и т. д.), одной из трудностей обучения иностранному языку является весьма ограниченная возможность общения с носителями языка и использования навыков разговорной речи. Поэтому важной задачей учителя является создание реальных и воображаемых ситуаций общения на уроке иностранного языка с использованием различных приемов работы. Не менее важным также считается приобщение к культурным ценностям народа-носителя языка.

В этих целях большое значение имеют аутентичные материалы - видеофильмы и различные видеоматериалы. Их использование способствует мотивированности речевой деятельности обучаемых» (Барменкова,1999). Наиболее важной в методическом плане является следующая классификация видеоматериалов. Во-первых, это специально разработанные учебные видеоматериалы, входящие в комплект современных учебно-методических комплексов (УМК). Доступными на всех этапах обучения являются учебные видеоматериалы. Они состоят из небольших эпизодов и имеют дополнительный дидактический материал. Здесь можно выделить 2 типа учебных видеоматериалов: непосредственно обучающие языку (direct teaching video); выступающие в качестве дополнительного источника для обучения языку (resource video). (Садовина, 2016). Основным достоинством данных видеоматериалов является то, что они понятны и разработаны для обучающихся с соответствующим уровнем владения языком. Они не являются аутентичными, поэтому рекомендуется ими не злоупотреблять, т.к. перед сопровождающими УМК материалами ряд преимуществ имеют аутентичные материалы (Harmer, 2000).

Многие преподаватели используют различные материалы (радиопередачи, документальные или художественные фильмы и другие естественные средства массовой информации), которые по своей сути учебными не являются, но вполне могут входить в учебный процесс. Такие средства называют неучебными аудиовизуальными средствами и стоят на втором месте. (Леонтьева, 1995 ). А 
третье место занимают программы, записанные с телевизионных каналов, которые называются off-air programs, т.е. программы, записанные непосредственно с эфира. Это программы новостей, документальные фильмы или научно-познавательные программы. В данной ситуации нужно помнить об уровне владения языком студентами, выбирать программы с учетом их продолжительности и соответствия языковому уровню обучающихся (Пичугова, 2015). Дж. Лонерган (Lonergan,1984) выделил четвертую категорию учебных видеоматериалов - видеофильмы, снятые самостоятельно студентами и преподавателем. Разработанные непосредственно преподавателями и студентами съёмка-видео в учебных целях характеризуется искусственно созданной речевой ситауцией. Студенты могут применить на практике полученные знания, проанализировать сформированность речевых навыков и развитие умения говорения. Существует несколько способов использования видеокамеры в процессе обучения иностранному языку. Самая захватывающая возможность - это использование видеокамеры самими студентами. Как отмечают Дж. Лонерган (Lonergan,1984) и М. Аллан (Allan,1991), процесс снятия фильма - это групповое предприятие, а процессы планирования и производства включают в себя значительное количество дискуссий (т.е. речевой продукт) в дополнение к изучаемому языку, используемому в самом фильме. Кроме того, процесс снятия фильма имеет тенденцию стать незабываемым. Выполняя функции оператора или играя роль в фильме, студенты обычно добиваются высоких результатов в изучении иностранного языка.

Мы выяснили, что одним из элементов личностно-ориентированного подхода к обучению являются съёмка видео в учебных целях с применением ролевых игр, т.к. дифференцированные задачи создают условия, в которых студенты с разными уровнями речевых умений и привычек работают с другими даже в режиме онлайн, не замечая этой разницы. Применение интерактивных методов обучения в 4 видах речевой деятельности предоставляют возможность развития творческих способностей во время занятий. При использовании информационных технологий посредством видеоматериалов необходимо помнить, что на всех этапах структурно должны быть задействованы все виды речевой деятельности (чтение, говорение, аудирование, письмо) и материалы: (введение новой лексики и грамматики, активизация в упражнениях, закрепление, текущий и итоговый контроль освоения материала). Отвечая принципам развивающего обучения, видео позволяет формировать лингвистические способности (через языковые и речевые упражнения), создавать ситуации общения и обеспечивать непосредственное восприятие и изучение культуры и истории страны изучаемого языка. Савицкая Н.С. в своей работе выделяет следующие особенности:

1. Применяемый видеоматериал должен соответствовать уровню знаний учащихся;

2. Наглядность должна использоваться в меру и показывать ее следует постепенно и только в соответствующий момент урока;

3. Просмотр видео должен быть организован таким образом, чтобы все учащиеся могли хорошо видеть демонстрируемый материал;

4. Необходимо четко выделять главное, существенное;

5. Детально продумывать пояснения, даваемые в ходе демонстрации видеоматериала;

6. Демонстрируемый видеоматериал должен быть точно согласован с изучаемым учебным материалом, соответствовать изучаемой теме (Савицкая, 2011).

Исходя из традиционного деления процесса работы с видеофильмом методисты разбивают на этапы и из предложенных Ю.А. Комаровой и Й. Вехаге, на наш взгляд, можно выделить четыре основных этапа:

1. Подготовительный или преддемонстрационный этап (pre-viewing);

2. Восприятие фильма или демонстрационный этап (while viewing);

3. Контроль понимания основного содержания или последемонстрационный этап ((post) after-viewing);

4. Развитие языковых навыков и умений устной речи или творческий этап;

Большинство отечественных и зарубежных методистов выделяют несколько основных этапов работы с видеоматериалами, а именно подготовительный, демонстрационный, последемонстрационный и творческий. В соответствии с предложенным делением первый, подготовительный этап нацелен на предварительное снятие языковых и лексических трудностей (студентам сообщается название видеопрактикума и предлагается догадаться о его содержании, вводится лексика, необходимая для его понимания и активного владения, дается страноведческий комментарий). Второй этап - просмотр видеоматериала. При просмотре видео развиваются умения восприятия информации. Цель этого этапа 
- обеспечить дальнейшее развитие языковой, речевой или социокультурной компетенций учащихся с учетом их реальных возможностей иноязычного общения. На данном этапе учащиеся осуществляют поиск, вычленение, фиксирование, трансформацию определенного лексического материала, грамматики, фонетики, могут делать записи. Третий этап - контроль понимания основного содержания. Цель - использовать видеоматериал как основу для развития умений по формированию высказывания. Для контроля понимания основного содержания можно использовать упражнения на множественный выбор, задания типа: «выбери правильный ответ», «расположи в правильной последовательности». Еще одним полезным упражнением является упражнение на активизацию лексики (учащимся предлагается вставить пропущенное и подходящее по смыслу слово в предложение из видеофрагмента). Четвертый творческий этап ставит своей целью развитие языковых навыков и умений устной речи. На этом этапе можно использовать задания типа: «составьте рассказ от имени одушевлённых/неодушевлённых существительных в тексте», «опишите актера», «докажите важность работы операторов сцены» (Закирова, 2015).

На каждом этапе есть ряд задач, выполнением которых и определяется эффективность всего аудиовизуального процесса. Каждый педагог лучше знает свою аудиторию, ему проще выбрать подход к любому из своих учеников. Как правило, такие уроки разрабатывают педагоги с большим опытом работы и по сути своей являющиеся новаторами. На педагогических семинарах обсуждаются только общие структуры проведения уроков подобного порядка. Педагог обязан просчитать каждый фрагмент урока во временном отрезке. Грамотный учитель просчитает заблаговременно каждую минуту, отведённую на объяснение новой темы в экспериментальном ключе (Бегунова, 2014). Одно или двухминутный фрагмент, изъятый из контекста, легко может дать достаточное количество языкового материала для проведения одного урока (Гуняшова, 2015). Демонстрация видео на занятиях - это небольшие фрагменты из видео (2-4 минуты), где детально и с максимальной наглядностью, вплоть до мельчайших нюансов (интонации, вербальные реакции, чувства, речевые обороты, речевые модули, последовательность действий, установки и т.д.), можно увидеть «работу» изучаемого инструмента. Видео на уроках это далеко не только иллюстрация, где суть просмотр и всё. Это постоянный диалог с группой, множество стоп-кадров (иногда до 8 за сюжет) с обсуждением и предположениями дальнейших действий, где происходит детальное изучение и одновременное закрепление изучаемой темы (Ибрагимова, 2016). Как правило, звучание текста более 4 минут перегружает кратковременную память и осложняет процесс восприятия. Текст, как правило, предъявляется для прослушивания два раза. Если обучающиеся не поняли текст после двукратного предъявления, целесообразно просмотреть текст фрагментами. На данном этапе широко используется прием «Застывший кадр», позволяющий нажатием кнопки «Пауза» еще раз просмотреть и прослушать иноязычную речь и ответить на поставленные преподавателем вопросы (Колесникова, 2001).

Перед показом необходимо отработать языковые средства с нормами речевого русского этикета, построить монологические и диалогические высказывания и входе показа видеоматериала с опорой на материалы пособий (фрагменты адаптированных текстов) студенты знакомятся с особенностями профессиональной деятельности.

Главная причина - незнакомые речевые средства, звучащие в фильме. Для эффективного использования видеоматериала необходимо новую лексику презентовать до просмотра фильма на экран посредством презентации с иллюстрациями, например, достопримечательности России, этикетные формулы и пословицы, используемые в кадре. Такая работа поможет студенту понять лексику видеоматериала, который последует после подготовительной работы. Студенты получают распечатки с именами, географическими названиями и ключевыми словами или читают их на доске. Дома предлагается по памяти записать увиденное в виде изложения.

Технология организации и проведения ролевой игры и обсуждение результатов

В процессе работы с видеофильмом мы разбиваем на этапы, предложенные Ю.А. Комаровой и Й. Вехаге (технология организации проведения четырёх этапов процесса работы с видеофильмом).

При изучении темы «Экскурсия по Москве» аудиовизуальные средства использовались с целью формирования навыков слушания, а также продуктивных навыков говорения. Мы использовали видео «Экскурсия по Москве» с Ириной Мозеловой https://www.youtube.com/watch?v=0qRe4wMWMWo или «Достопримечательности Москвы Sightseeing in Moscow» МАПРЯЛ https://www.youtube.com/watch?v=_xYE91727m8. Работа с данным видеофрагментами проходила в 
несколько этапов. Перед началом работы с видео https://www.youtube.com/watch?v=0qRe4wMWMWo студенты получили раздаточный материал.

\section{Этапы работы с видеофрагментом}

Преддемонстрационный этап. Цель - снятие возможных языковых трудностей по теме «Город» и грамматической теме «Творительный и Родительный падежи в значении места», активизация новой лексики, стимулирование познавательного интереса студентов.

1. Составьте словосочетания, поставив слова в скобках в нужной форме.

Парк (культура), академия (наука), столица (Россия), территория (Кремль), здание (правительство), берег (река), парк (отдых), памятник (архитектура), гости (Москва), центр (наука).

2. Студентам предлагается найти здания на предложенной карте Москвы (использовать Тв и Род.п.).

3. Как вы понимаете данные выражения? Найдите эквиваленты в родном языке. Придумайте ситуации, в которых можно их употребить.

Он не может найти место под солнцем. Ничто не вечно под луной. Парить между небом и землёй. Родиться под счастливой звездой. У него нет крыши над головой.

Демонстрационный этап. Цель - развитие навыков изучающего слушания с полным пониманием содержания текста с опорой на видеоряд; развитие рецептивных умений. Видеофрагмент

Доступно по адресу: https:/www.youtube.com/watch?v=0qRe4wMWMWo

Фрагмент 1. (0:22)-стоп кадр

Давайте вспомним, глаголы движения: дойти до сущ+ Род.п, подойти к сущ+Дат.п., идти по сущ+ Дат.п

1. Описать местонахождение зданий.

Фрагмент 2. (0:53)-стоп кадр

1. Кто основал Москву?

2. Где находится памятник основателя ?

Фрагмент 3. (0:53-1:36)

1. Что такое ДУМА и где она находится?

2. $\quad$ Где стоит памятник Карлу Марксу?

Фрагмент 4. (1:45)-стоп кадр

1. Описать местонахождение зданий на площади Революции

Фрагмент 5. (2:24-3:07)-кадр

1. $\quad$ Где находится нулевой километр и что там делают люди?

2. Сколько круглых башен в Московском Кремле и где они находятся?

Фрагмент 6. (3:08)-кадр

1. Описать местонахождение зданий на Красной площади?

Фрагмент 7. (3:08-4:37)-кадр

1. Где расположены бутики известных дизайнеров?

2. $\quad$ Что находится перед ГУМом?

3. Расскажите о Мавзолее Ленина?

4. Что вы узнали о Спасской башне?

5. $\quad$ Где находится Храм Василия Блаженного и когда его построили?

Каждый студент получил карточку с достопримечательностью Москвы. Его задача описать это место так, чтобы остальные догадались, о чём идет речь.

\section{Последемонстрационный этап}

После просмотра проводятся следующие виды работы:

a) повторение и закрепление речевых блоков;

б) комментирование коммуникативных приемов, просмотренных в видеоматериале;

Обсуждение. Студентам соотносят увиденное с реальными ситуациями в их жизни, в их стране и анализируют сходства и различия в культуре.

Проверьте себя, знаете ли вы свою родину

- Сколько турков проживает по всему миру?

- Сколько климатических зон в Турции?

- Какую площадь занимает территория Турция?

- Назовите столицу и крупные города. 
- Назовите автора гимна Турции.

Чтение по теме. Можно предложить студентам проблемные или информационные тексты по теме видео-сюжета для просмотрового чтения и обсуждения. После просмотра студентам предстоит выполнить тест «Москва» из учебного пособия (Попова, 2009). на понимание фрагмента, ответить на проблемные вопросы. Все задания должны быть направлены на формирование речевых навыков.

Послетекстовые задания:

Ответьте на вопросы к тексту

1. $\quad$ Где располагается Кремль?

2. Что находится у стен Кремля?

3. Какие архитектурные памятники украшают Красную площадь?

4. Где располагается городской Парк культуры и отдыха?

5. Какие государственные учреждения находятся в столице России?

6. Где хранятся картины великих художников?

7. Почему Москва всё время меняется?

\section{Поставьте слова в скобках в нужной форме}

1. Мы попросили (преподаватель) рассказать о столице России.

2. Все, кто приезжает в Москву, любят фотографироваться (Красная площадь).

3. $\quad$ Городской Парк культуры и отдыха располагается (берег реки Москвы).

4. В Москве находятся МГУ и Университет (дружба народов).

5. (Москва) нет возраста, потому что она не стареет.

\section{Вместо точек поставьте необходимые по смыслу глаголы в нужной форме}

1. Вчера на уроке преподаватель о Москве 2. В Кремле древние храмы. 3. Если вы первый раз приехали в Москву, надо ................. на Красной площади. 4. В столице ... ...интересные музеи, выставки, известные театры. 5. Во всём мире

Российскую техническую академию. 6. Картины великих художников в Третьяковской картинной галерее. 7. В столице ...................новые магазины, банки, жилые дома и школы. 8. Москве уже 860 лет, но она не

\section{Составьте план текста, дописав пропущенные пункты}

1.

2. Кремль- это сердце Москвы.

3.

4. Москва - огромный современный город.

5.

6. Москва - это центр науки и культуры.

7. Москва - это многомиллионный город.

8. У Москвы нет возраста.

Ролевая игра. После демонстрации предложенного видеоматериала студенты могут подготовить и инсценировать данные ролевые игры также в режиме онлайн.

\section{Ролевая игра «Экскурсия по Москве» и Телепередача «Все о России»}

Для закрепления нового материала необходимо интегрировать (в данном образовательном «поле») несколько интерактивных методов обучения, построенной на основной теме видеоматериала «Достопримечательности России». В данной работе поделимся своим опытом применения ролевой игры посредством видеоматериалов на уроках русского языка как иностранного. К примеру, преподавателем разрабатывается ролевая игра «Экскурсия по Москве», позволяющая привязать изучаемый материал к формированию навыков коммуникативной компетенции в данной речевой ситуации. Задача состоит в том, чтобы выяснить значение ролевой игры «Экскурсия по Москве» как одного из интерактивных методов преподавания русского языка в вузе. Выдуманные экскурсии являются эффективным методом обучения, развивающий наблюдательность, способствуют накоплению сведений, формированию визуальных впечатлений. Использование такого рода материалов необходимо и крайне важно, так как они создают иллюзию участия в реальной жизни страны изучаемого языка, а это в свою очередь стимулирует студентов на дальнейшее изучение языка и повышает их мотивацию к обучению. (Ступникова, 2017). Ролевая игра «Экскурсия по Москве» должна быть спланирована: тема экскурсии; объект экскурсии; время проведения; оформление результатов. Подготовка вымышленной экскурсии происходит в следующей последовательности: 
- Выбрать объект экскурсии и детально исследовать;

- Определить маршрут (перемещение до объекта экскурсии);

- Провести беседу со студентами ( сообщается тема и цель экскурсии, повторяется нужный теоретический материал).

Задачи ролевой игры «Экскурсия по Москве»:

1.Образовательные:

- Расширить знания о достопримечательностях Москвы, туризме и работе гида;

- Продолжать формировать умение действовать в соответствии с ролью ( экскурсовод, турист(клиент), переводчик);

- Формулировать проблему и ее постановку, определять способы решения проблемы, трудности, выход из «тупика»;

- Овладеть приемами вербальной и невербальной коммуникации;

- Закреплять знания о главном городе России - Москве;

2. Развивающие:

- Обогащать словарный запас;

- Развивать монологическую и диалогическую речь;

- Развивать память, внимание, любознательность;

3. Воспитательные:

- Воспитывать дружеские, добрые взаимоотношения в процессе игры;

После демонстрации видеоматериала о городе Москве студенты могут подготовить и инсценировать предлагаемую ролевую игру. Знакомство с главным городом России - Москвой и достопримечательностями. Развешиваются иллюстрации и вывески о городе Москве. Перед ними ставится следующая задача: все студенты в роли туриста и переводчика делятся на пары и рассаживаются в аудитории в расстановке посадочных мест автобуса. (туристы (семья: мама, папа, дети) или иностранец с переводчиком, экскурсовод: встречает клиентов, рассказывает о городе, используя презентацию и журналы, демонстрирует сувениры из Москвы). А в режиме онлайн каждый студент перед своим компьютером «вживается в роль». Роль экскурсовода туристской компании, туриста и переводчиков постоянно меняется. Роль преподавателя ограничивается только объяснением задачи, а дальше студент играет самостоятельно и подбирает те языковые средства, которые он считает необходимыми в ситуации. При этом каждый из студентов заранее подготовил свое коммуникативное задание по информации об историческом или культурном обьекте России. Экскурсовод туристской компании приступает к презентации экскурсионного тура с помощью интерактивной доски или со своего компьютера и в процессе туристы на русском языке задают максимально точный вопрос, а представители дают максимально точный ответ, используя изученный лексико - грамматический материал. Некоторые туристы, прибывшие на экскурсию со своим переводчиком английского или турецкого языков , задают вопросы экскурсоводу, при этом не только отрабатываются навыки синхронного перевода и построения собственного высказывания. Задачами преподавателями становится прививание навыков нахождения подходящих языковых форм для выражения глубинных смыслов и формирование автоматического «нанизывания» этих форм в процессе динамической речи и межъязыкового перевода (Козан, 2016). Выполнившие задачу в роли экскурсовода туристской компании, переводчика и туриста, далее студенты выступают в роли наблюдателей и экспертов по оценке выбора моделей речевого этикета, грамотности употребления конструкций с глаголами точности задаваемых вопросов и полноты ответов, а также невербальному поведению участников ролевого общения (Мырзабекова, 2020). Каждый из участников диалога получает оценку эксперта по стобалльной шкале, которые записываются на доске. Преподаватель осуществляя контроль усвоения знаний и формирования навыков в конце игры дает поощрительные и штрафные баллы за фонетическое оформление диалогов, а также эксперту за умение аргументировать оценку, выставленную по тому или иному критерию.

\section{Ролевая игра «Телепередача «Все о России»}

Для закрепления видеоматериала «Достопримечательности России» можно применить ролевую игру телепередачу «Все о России». Программа для зрителей, которые отправляются на прогулку по улицам и заповедным уголкам Москвы и других городов России. Ролевая игра телепередача «Все о России» должна быть спланирована в режиме онлайн : тема ТВ передачи; объект; 
время проведения; оформление результатов. Подготовка вымышленной ТВ программы происходит в следующей последовательности:

- Выбрать объект и детально исследовать;

- Предварительная самостоятельная работа студента (презентация культурного или исторического обьекта);

- Провести беседу со студентами ( сообщается тема и цель, повторяется нужный теоретический материал).

Задачи ролевой игры «Телепередача «Все о России»:

1.Образовательные:

- Формировать расширения представлений о телевизионном искусстве, как о значимом источнике информации

- Формировать умение действовать в соответствии с ролью (ведущий программы, гости программы-директор музея, краевед, исследователь, эксперт );

2. Развивающие:

- Формировать умение самостоятельно решать новые проблемы и сталкиваясь с новыми конфликтами

- Строить монологические и диалогические высказывания адекватно целям и сферам общения на основе изученного лексико-грамматического материала;

- Формировать навыки театральной деятельности;

- Обогащать языковой запас и страноведческие знания ;

Перед студентами ставится следующая задача: в аудитории создать обстановку телестудии, интерактивная доска с презентациями, карта России, микрофоны, подготовить места для телеведущего, телезрителей и гостей студии (директор музея, краевед, исследователь). Все студенты-гости студии для создания воображаемой ситуации рассаживаются в вымышленной телестудии. А в дистанционном формате студенты-телеведущие создают обстановку телестудии в комнате или применяют реалистичное отображение объекта с использованием 3D-технологий. Роли телеведущего, телезрителей и гостей студии постоянно меняются. Количественный состав экспертов может варьироваться от 3 до 5 человек. Телеведущий приглашает гостей занять места за столом в студии (в режиме онлайн подключает к своей презентации). Он дает команду, когда начинать трансляцию выпуска программы. Начинает интерактивную экскурсию по городу и беседует с гостями программы . Затем предлагает продолжить просмотр видеосюжетов (снятых заранее) гостями студии, которые далее расскажут о достопримечательностях России или своих исследованиях ( каждый из студентов заранее подготовил свое коммуникативное задание по информации об историческом или культурном обьекте). После завершения имитационной телепередачи эксперты осуществляют экспертизу всей деятельности участников игры; готовят отчет по анализу идей, разработанных индивидуально и коллективно, по исполнению своих ролей, по уровню аргументации и выполнению заданных норм ведения дискуссии на основе правил игры и соответствующих методик оценивания (Панфилова, 2003). Преимуществом данной игры является то, что она достаточно мобильна, легко адаптируется и модифицируется для разных сфер как туризм, коммуникация и телевидение, для специалистов любого профиля. Для этого достаточно лишь разработать соответствующую модель ролевой игры и ситуации в рамках конкретной профессиональной деятельности.

\section{Творческий этап}

Творческий проект видеосъёмка виртуальной экскурсии по городу России. Тема: "Виртуальная экскурсия по городу России". Целью творческого проекта явдяется разработать виртуальную экскурсию по городу России с применением видеокамер или технологий панорамной съемки (http://360cities.net). Подобный способ позволяет экскурсоводу не только представить достопримечательности одного из городов России, но показать их расположение относительно друг друга. Видеосъёмка виртуальной экскурсии необходима и крайне важна, так как она создаёт иллюзию участия в реальной жизни страны, а это в свою очередь обощает языковой запас и страноведческие знания.

Дополнительные материалы представлены ниже:

1. https://www.youtube.com/watch?v=0qRe4wMWMWo

2. «Дорогие ребята! Здравствуйте! Это я - профессор Чудаковский. Мне 75 лет. Я родом из Москвы, но сейчас живу на Марсе. Я создал удивительную машину, с помощью которой можно 
путешествовать во времени. И у вас появилась такая возможность побывать в прошлом и узнать историю Москвы, или перенестись назад в настоящее и прогуляться по улицам. Смелее! В путь! Портал времени уже открыт. Чтобы не заблудиться во времени вам, ребята, будет дана карта с картинками. Рассаживайтесь в машине времени поудобнее, я буду вашим пилотом. Путешествие наше будет виртуальным, мы не будем выходить на улицу, но сможем всё увидеть с помощью монитора машины времени. Вам интересно? Портал времени открылся, поехали! (virtualnaya_ekskursiya_po_gorodu_etot_gorod_zovut_232902.html). Начнём нашу долгожданную экскурсию по Москве. Это Московский Государственный Университет. Новое здание университета находится на станции метро «Университет», а старое - в центре Москвы, на Моховой улице. До него можно доехать на метро, до станции «Охотный ряд» или до станции «Библиотека Имени Ленина». Старое здание МГУ не очень большое, но красивое. Рядом памятник М. В. Ломоносову. Он основал Московский университет в 1755 году. Слева находится Библиотека МГУ, а справа - ИСАА. ИСАА это тоже часть МГУ.и т.д.» ( Караванова, 2009).

3. Подготовьте экскурсию по вопросному плану:

1. ФИО, дата рождения и место рождения.

2. Где находится город, о котором вы будете рассказывать?

3. Какая природа, какой климат, какие сезоны в этом городе? Есть ли там реки, горы, пустыни?

4. Сколько километров от этого города до столицы?

5. Сколько человек живёт в этом городе?

6. В каком году основан этот город? Когда отмечают день города?

7. Расскажите об истории возникновения города. (Какие знаменитые люди жили и какие события происходили там? Напишите даты).

8. Расскажите о достопримечательностях этого города (что где находится, используйте предлоги места родительного падежа ВОЗЛЕ, ОКОЛО, У, НАПРОТИВ, СПРАВА ОТ, СЛЕВА ОТ, НЕ/ДАЛЕКО ОТ, ПОЗАДИ, ВПЕРЕДИ...)

9. Каких культурных мест много и каких культурных мест мало или нет в этом городе? (Например, театры, музеи, парки, кинотеатры и другие места развлечений).

10. Какие места вы можете посоветовать туристам в этом городе?

Выводы. В работе представлены разнообразные виды работ по обучению русскому языку на всех этапах работы с видеоматериалом и по применению ролевых игр «Экскурсия» и телепередача «Все о России» в интеграции (в данном образовательном «поле»), способствующих повышению качества обучения и интереса к изучению предмета, обучающих естественной коммуникации, позволяющих активизировать студентов в процессе освоения русского языка и побуждающих к совершенствованию своих коммуникативных умений, расширению, углублению профессиональных знаний и обогащению их языкового запаса и страноведческих знаний. Результаты работ подтверждают целесообразность и эффективность применения ролевых игр при обучении. Скарселла и Крукалл провели исследование, чтобы показать, как моделирование ситуаций облегчает изучение иностранного языка. Они считают, что студенты овладевают языком в следующих случаях:

- Когда они получают большое количество лёгкого для усвоения материала;

- Когда они принимают активное участие в занятиях;

- Когда они находятся в позитивной дружественной обстановке (Scarcella, 1990).

Мы полагаем, что выбор роли - один из важнейших аспектов ролевой игры, поскольку он связан со степенью самостоятельности студента при подборе языковых и речевых средств и сформированности умения самопрезентации в определенной ситуации. Развлечение не является целью ролевой игры, но в то же время она не должна быть скучной. Возможность представить себя в роли, которая для студента неординарна интересна, неприемлема в обычной жизни, связана с риском требует особых способностей и т.д. Данные игры способствуют накоплению умений и навыков работы в коллективе, помогают оценить новые социальные отношения в органической связи с этикой профессиональной деятельности, расширяют личностные возможности студентов, дают ощущение уверенности в себе. При подготовке и проведении данных ролевых игр после просмотра видеоматериала, студенты применяют усвоенные знания в условиях, имитирующих реальную социальную и профессиональную практику взаимодействия с представителями иных культур, осваивают опыт эффективного межкультурного взаимодействия и воссоздают акт естественной коммуникации, изображая вымышленных персонажей. Эти вымышленные игры 
представляют собой условное воспроизведение ее участниками практической деятельности людей, создавая тем самым условия для реальной коммуникации. Ролевые игры дают возможность студентам стать «актерами» данного видеоматериала, «вмешаться» в действия и поступки актеров, попытаться изменить ход событий. Студенты создают новые ситуации, которые не были в видеофрагменте, сами становятся «режиссерами» нового видеосюжета, решая новые проблемы и сталкиваясь с новыми конфликтами. Дейв Уиллис выделяет следующую положительную характеристику использования видео в процессе обучения: - видеоматериалы легко используются при различных видах работы: индивидуальной, парной, групповой, коллектиой (Willis, 1983). На этих занятиях в условиях коллективной работы студенты приобретают не только навыки говорения русского языка, но и ценностные ориентациии навыки социального взаимодействия, присущие будущему специалисту. Преимущество данной формы работы заключается в том, что в силу высокой эмоциональной нагрузки русский как иностранный язык уже перестает быть целью, он словно отходит на второй план, становится средством достижения коммуникативной цели. На базе изученного материала были сделаны следующие выводы:

1. успешное использование ролевых игр и творческой работы после демонстрации видеоматериалов гарантирует формирование практического владения русским языком на всех уровнях обучени русскому языку;

2. на уровне основного образования студенты могут ориентироваться в простых текстах, чему особенно способствует успешное использование ролевых игр после просмотра видеоматериалов;

3. использование ролевых игр после демонстрации видеоматериалов на уроках русского языка предлагает большой выбор методов и способов работ с ним, что облегчает интеграцию студентов в образовательный процесс освоения русского языка и культуры;

4. применение ролевых игр после демонстрации видео позволяет активизировать студентов в процессе освоения русского языка, побуждает к совершенствованию своих коммуникативных умений, расширению, углублению профессиональных знаний и обогащению их языкового запаса и страноведческих знаний ;

5. формирует умение соотносить языковые средства с нормами речевого поведения носителей русского языка ;

6. помогает преодолеть стеснительность, мешающую свободно употреблять в речи слова чужого языка, позволит им более уверенно чувствовать себя, определять стратегии и тактики речевого поведения и соответственно, выстраивать высококвалифицированную профессиональную речь;

На сегодняшний день на рынке образовательных услуг перед вузами стоит задача повышения собственной конкурентоспособности, которая, прежде всего, определяется инновационными образовательными технологиями, способствующими качественной подготовке обучающихся. В индустриальную эпоху инновационных технологий и переход на дистанционное обучение в условиях пандемии необходим постоянный поиск новых интегрированных принципов и интерактивных методов обучения, для того чтобы сформировать стойкую положительную мотивацию студентов в отношении русского как иностранного языка и добиться наиболее оптимального уровня усвоения учебного материала.

Ссылка на данную статью: Мырзабекова М., Ахметова Н. (2020). Использование ролевых игр на основе видеоматериалов, как средство формирования коммуникативных компетенций в изучении русского языка как иностранного. Материалы Международной практической интернетконференции «Актуальные проблемы науки» [Challenges of Science]. Выпуск III, стр. 118-130. https://doi.org/10.31643/2020.017

\section{Литературы}

Allan M. Teaching English with Video. L.: Longman, 1991. 296 p.

Harmer J. How to Teach English. L: Longman, 2000. 198 p

Lonergan J. Video in Language Teaching. Cambridge: Cambridge University Press, 1984.

Scarcella, R.- Crookall, D, Simulation, gaming and language learning, Newbury House Publishers, New York, 1990 C.13-15 
Willis D. The potentials and Limitations of Video // Videoapplications in ELT. - Pergamon Press. - 1983. - . C. 17

Барменкова О. И. Видеозанятия в системе обучения иностранной речи / О. И. Барменкова // Иностранные языки в школе. 1999. - №3. - С. 21

Бегунова Я.А. Приемы использования видеоматериалов в формировании коммуникативной компетенции на английском языка // Ярославский педагогический вестник. 2014. № 1. С. 247-250.

Гуняшова Г. А. Использование видеоматериалов в обучении аудированию на уроке иностранного языка.// Вестник Кемеровского государственного университета.2015. - № 3. - С. 34 - 37.

Закирова Г.Ш. Опыт работы по организации учебного курса: английский язык для российских преподавателей технических дисциплин // Магия ИННО: новое в исследовании языка и методике его преподавания Материалы Второй научнопрактической конференции. 2015. № 5. С. 335 _340.

Ибрагимова М.М. Использование видео на начальном этапе обучения английскому языку // Сборник материалов II Всероссийской научно-практической конференции. 2016. № 2. С. 42-48.

Караванова Н.Б. Читаем и всё понимаем: Пособие по чтению и развитию речи для иностранцев, изучающих русский язык , М.: Русский язык. Курсы,2009 .С.46

Козан О. Методика функциональный синтаксис и формирование семантической осознанности в процессе обучения РКИ: пример турецкоязычной аудитории, «Русский язык за рубежом»: Государственный институт русского языка им. АС Пушкина. 2016. С. 86

Колесникова И.Л. Долгина О.А. Англо-русский терминологический справочник по методике преподавания иностранных языков. - СПб.: Изд-во «РусскоБалтийский информационный центр «БЛИЦ», «Cambridge University Press». 2001г. С.101 $-106$.

Леонтьева, Т. П. Опыт и перспективы применения видео в обучении иностранным языкам / Т.П. Леонтьева // Нетрадиционные методы обучения иностранным языкам в вузе: материалы респ. конференции. -Минск, 1995. - С. 61-74

Мельник О.Ф. Инновационность образовательных учреждений: подходы к описанию феномена (Текст) / О.Ф. Мельник // Альманах современной науки и образования. 2008. - №10-1. - С. 114-117.

Мырзабекова М, Умирбекова Р, Буряченко, Т. (2020). Применение Ролевых Игр В Формировании Навыков Речевого Этикета Русского Языка В Коммуникативной Подготовке Студентов Специальности «Туризм» в Турции Turkish Studies, 15(2), 2020- C. 1177. https://dx.doi.org/10.29228/TurkishStudies.41836

Панфилова А.П. Игротехнический менеджмент, С.-Петербург. 2003 с. 151

Пичугова И.Л. К вопросу об использовании видеоматериалов при обучении иностранному языку профессионального общения .2015- C. 65

Попова, Т.В. Л.В. Архипова, Т.П. Баркова, Т.В. Губанова, Н.Г. Посадская, Л.А. Шахова ; под общ. ред. д-ра филол. наук, проф. И.М. Поповой Русский язык : учеб. пособие для студентов-иностранцев подготовительного факультета : в 2 ч. /. - 2-е изд., испр. и доп. - Тамбов : Изд-во Тамб. гос. техн. ун-та. 2009. -Ч. 1. - 192 с. - 100 экз. - ISBN 978-5-8265-07933. C-53

Савицкая Н.С. Даниленко Р.М. Использование аутентичных видеоматериалов при формировании навыков говорения на занятиях по иностранному языку//Филологические науки. Вопросы теории и практики. - 2011. - №2(9). - С. 152-153.

Садовина Л.В. Применение видеоматериалов в процессе обучения английскому языку. Методические материалы. - ЙошкарОла ГБУ ДПО Республики Марий Эл «Марийский институт образования», 2016 -28 с.

Ступникова С.А. Формирование лексических навыков у учащихся начальной школы на основе мультипликационного фильма «Эверополис» Екатеринбург .2017. С. 24

Электронный источник, дата обращения 05.05.2018: https://xn--j1ahfl.xn-p1ai/library/virtualnaya_ekskursiya_po_gorodu_etot_gorod_zovut_232902.html

Электронный источник, дата обращения 27.03. 2020: https://www.youtube.com/watch?v=0qRe4wMWMWo

Электронный источник, дата обращения 31.05.2020: https://www.youtube.com/watch?v=_xYE91727m8

\section{References}

Allan M. Teaching English with Video. L.: Longman, 1991. 296 p. (In English).

Barmenkova O. I. Videozanyatiya v sisteme obucheniya inostrannoy rechi / O. I. Barmenkova // Inostrannyye yazyki v shkole [Video lessons in the system of teaching foreign speech / O. I. Barmenkova // Foreign languages at school]. 1999. - No. 3. - P. 21. (In Russan).

Begunova Ya.A. Priyemy ispol'zovaniya videomaterialov v formirovanii kommunikativnoy kompetentsii na angliyskom yazyka // Yaroslavskiy pedagogicheskiy vestnik [Techniques for using video materials in the formation of communicative competence in English // Yaroslavl Pedagogical Bulletin]. 2014. No. 1. S. 247-250. (In Russian).

Electronic source, accessed on 05.05.2018: https://xn--j1ahfl.xn-p1ai/library/virtualnaya_ekskursiya_po_gorodu_etot_gorod_zovut_232902.html (In Russian)

Electronic source, accessed on 27.01. 2017: https://www.youtube.com/watch?v=0qRe4wMWMWo (In Russian)

Electronic source, accessed on 31.05.2020: https://www.youtube.com/watch?v=_xYE91727m8 (In Russian)

Gunyashova G.A. Ispol'zovaniye videomaterialov v obuchenii audirovaniyu na uroke inostrannogo yazyka.// Vestnik Kemerovskogo gosudarstvennogo universiteta [The use of video materials in teaching listening in a foreign language lesson. // Bulletin of the Kemerovo State University]. 2015. - No. 3. - P. 34 - 37.

Harmer J. How to Teach English. L: Longman, 2000. 198 p. (In English).

Ibragimova M.M. Ispol'zovaniye video na nachal'nom etape obucheniya angliyskomu yazyku // Sbornik materialov II Vserossiyskoy nauchno-prakticheskoy konferentsii [Using video at the initial stage of teaching English // Collection of materials of the II AllRussian scientific and practical conference]. 2016. No. 2. S. 42-48.

Karavanova N.B. Chitayem i vso ponimayem: Posobiye po chteniyu i razvitiyu rechi dlya inostrantsev, izuchayushchikh russkiy yazyk, M.: Russkiy yazyk [We read and understand everything: A manual on reading and speech development for foreigners studying Russian, M.: Russian language. Courses], 2009, p. 46

Kolesnikova I.L. Dolgina O.A. Dolgina O.A. Anglo-russkiy terminologicheskiy spravochnik po metodike prepodavaniya inostrannykh 
yazykov. - SPb.: Izd-vo «RusskoBaltiyskiy informatsionnyy tsentr «BLITS» [English-Russian terminological reference book on methods of teaching foreign languages. - SPb.: Publishing house "Russian-Baltic information center" BLITZ "],"Cambridge University Press". 2001 Pp. 101 - 106.

Kozan O. Metodika funktsional'nyy sintaksis i formirovaniye semanticheskoy osoznannosti v protsesse obucheniya RKI: primer turetskoyazychnoy auditorii, «Russkiy yazyk za rubezhom»: Gosudarstvennyy institut russkogo yazyka im. AS Pushkina [Methodology functional syntax and the formation of semantic awareness in the process of teaching RFL: an example of a Turkish-speaking audience, "Russian language abroad": State Institute of the Russian language named after AS Pushkin]. 2016.S. 86

Leont'eva, T.P. Opyt i perspektivy primeneniya video v obuchenii inostrannym yazykam / T.P. Leont'yeva // Netraditsionnyye metody obucheniya inostrannym yazykam v vuze: materialy resp. konferentsii [Experience and prospects of using video in teaching foreign languages / T.P. Leontyeva // Non-traditional methods of teaching foreign languages at the university: materials of the rep. conferences]. - Minsk, 1995. - S. 61-74

Lonergan J. Video in Language Teaching. Cambridge: Cambridge University Press, 1984. (In English).

Melnik O.F. Innovatsionnost' obrazovatel'nykh uchrezhdeniy: podkhody k opisaniyu fenomena (Tekst) / O.F. Mel'nik // Al'manakh sovremennoy nauki i obrazovaniya [Innovativeness of educational institutions: approaches to describing the phenomenon (Text) / O.F. Melnik // Almanac of modern science and education]. 2008. - No. 10-1. - S. 114-117.

Myrzabekova M, Umirbekova R, Buryachenko, T. (2020). Primeneniye Rolevykh Igr V Formirovanii Navykov Rechevogo Etiketa Russkogo YAzyka V Kommunikativnoy Podgotovke Studentov Spetsial'nosti «Turizm» v Turtsii Turkish Studies [The Usage Of Role-Playing Games İn Speaking Etiquette Skills Development İn Russian Language For Communicative Preparation Of Students In The Specialty “Tourism” İn Turkey, Turkish Studies], 15 (2), 2020- C. 1177. https://dx.doi.org/10.29228/Turkish Studies.41836

Panfilova A.P. Igrotekhnicheskiy menedzhment [Game technical management], St. Petersburg. 2003 p. 151

Pichugova I.L. K voprosu ob ispol'zovanii videomaterialov pri obuchenii inostrannomu yazyku professional'nogo obshcheniya [On the use of video materials in teaching a foreign language for professional communication]. 2015 - P. 65

Popova, T.V. L.V. Arkhipova, T.P. Barkova, T.V. Gubanova, N.G. Posadskaya, L.A. Shakhova; under total. ed. Dr. philol. Sciences, prof. THEM. Popova Russian language: textbook. manual for foreign students of the preparatory faculty: 2 hours /. - 2nd ed., Rev. and add. - Tambov: Publishing house of Tamb. state tech. un-that. 2009. -Ch. 1.- 192 p. - 100 copies - ISBN 978-5-82650793-3. S-53

Sadovina L.V. Primeneniye videomaterialov v protsesse obucheniya angliyskomu yazyku. Metodicheskiye materialy. - Yoshkar-Ola GBU DPO Respubliki Mariy El «Mariyskiy institut obrazovaniya» [The use of video materials in the process of teaching English. Methodical materials. - Yoshkar-Ola GBU DPO of the Republic of Mari El "Mari Institute of Education"], 2016 -28 p.

Savitskaya N.S. Danilenko R.M. Ispol'zovaniye autentichnykh videomaterialov pri formirovanii navykov govoreniya na zanyatiyakh po inostrannomu yazyku//Filologicheskiye nauki. Voprosy teorii i praktiki [The use of authentic video materials in the formation of speaking skills in foreign language classes // Philological sciences. Questions of theory and practice]. - 2011. - No. 2 (9). - S. 152-153.

Scarcella, R.- Crookall, D, Simulation, gaming and language learning, Newbury House Publishers, New York, 1990 C.13-15

Stupnikova S.A. Formirovaniye leksicheskikh navykov u uchashchikhsya nachal'noy shkoly na osnove mul'tiplikatsionnogo fil'ma «Everopolis» Yekaterinburg [Formation of lexical skills among primary school students based on the animated film "Everopolis" Yekaterinburg]. 2017. P. 24

Willis D. The potentials and Limitations of Video // Videoapplications in ELT. - Pergamon Press. - 1983. - . C. 17. (In English).

Zakirova G.Sh. Opyt raboty po organizatsii uchebnogo kursa: angliyskiy yazyk dlya rossiyskikh prepodavateley tekhnicheskikh distsiplin // Magiya INNO: novoye $\mathrm{v}$ issledovanii yazyka i metodike yego prepodavaniya Materialy Vtoroy nauchnoprakticheskoy konferentsii [Experience in organizing a training course: English for Russian teachers of technical disciplines // Magic INNO: new in the study of language and methods of teaching it Materials of the Second Scientific and Practical Conference]. 2015. No. 5.P. 335_340. 